\title{
CONVERSATIONAL ENGLISH FOR TOURIST ESCORTS
}

\author{
Caezar D. Pamin, Ph. D. \\ Faculty, \\ Laguna State Polytechnic University, \\ Santa Cruz, Laguna, \\ Philippines
}

Article DOI: https://doi.org/10.36713/epra6888

DOI No: 10.36713/epra6888

\begin{abstract}
This study develops and validate a practical English handbook for tourist escorts. Thirty (30) tourist escorts in the province of Laguna and (10) English Professors of selected HEIs were the respondents of the study. The researcher answers the following questions: (1) What is the mean level of scores given by the local tourist guides in the developed practical English handbook with respect to: usability, consistency, adaptability, appropriateness, aesthetic value? (2) What is the mean level of scores given by the English experts with respect to: usability, consistency, adaptability, appropriateness, aesthetic value? (3) is there a significant difference in the rating among the tour guides and English experts based on the following criteria: usability, consistency, adaptability, appropriateness, aesthetic value?

Weighted the mean and standard deviation were used to determine the assessment of the expert evaluators. As observed in the treatment done in this study, the following were evident: The over-all mean of 4.20 revealed that the Practical English Handbook was extremely acceptable in terms of appropriateness given by local tourist guides. And the over-all means of 3.85, 3.99, 4.05 and 3.98 respectively indicated very acceptable in terms of usability, consistency, adaptability and aesthetic value.

The over-all mean of 4.40, 4.24, 4.30 and 4.40 respectively revealed that the Practical English handbook was extremely acceptable in terms of usability, consistency, adaptability, appropriateness and aesthetic value as rated by the English experts.

The computed t-values of 2.46, 2.16 and 2.26 had p-values of $0.024,0.042$ and 0.035 were all less than the alpha 0.05 level of significance with indicated that there was significant difference on the ratings' given by the local tourist guides English experts on the usability, consistency and aesthetic value respectively. While the $t$-values of 0.289 and 0.605 which were greater that alpha 0.05 level of significance were verbally interpreted as not significant based on the ratings' given by the local tourist and English experts on the adaptability and appropriateness.
\end{abstract}

\section{BACKGROUND OF THE STUDY}

Republic Act No. 9593, in the Pursuant to the authority vested in the Secretary of the Department of Tourism under Section 107 of the Act, otherwise known as the Tourism Act of 2009, the following implementing Rules and Regulations (IRR) are hereby promulgated under Section 1 which is the Declaration of Policy stating that:

The State declares tourism as an indispensable element of the national economy and an industry of national interest and importance, which must be harnessed as an engine of socio-economic growth and cultural affirmation to generate investment, foreign exchange and employment, and to continue to mold an enhanced sense of national pride for all Filipinos.

Towards this end, the State shall seek to : (a) Ensure the development of Philippine tourism that is for and by the Filipino people, conserve and promote their heritage, national identity and sense of unity: (b) Recognize sustainable tourism development as integral to the national socio-economic development efforts to improve the quality of life of the Filipino people, 
providing the appropriate attention and support for the growth of this industry: (c) Promote a tourism industry that is ecologically sustainable, responsible, participative, culturally sensitive, economically viable and ethically and socially equitable for local communities: (d) Create a favorable image of the Philippines within the international community, thereby strengthening the country's attraction as a tourism destination and eventually paving the way for other benefits that may result from a positive global view of the country: (e) Develop a country as a prime tourist hub in Asia, as well as center of world congresses and conventions, by promoting sustainable tourism anchored principally on the country's history, culture and natural endowments, and ensuring the protection, preservation and promotion of these resources: and (f) Encourage private sector participation and Agritourism for countryside development and preservation of rural life.

In the middle of 1990s, the LGU poured in additional investment and more attention to the potential of the place and connected it to a municipal enterprise.

Also, the United Nations' Resolution as adopted by the General Assembly on December 18, 1992, specifically states in Article 1 that:

States shall protect the existence and the national or ethnic, cultural, religious and linguistic identity of minorities within their respective territories and shall encourage conditions for the promotion of that identity.

States shall adopt appropriate legislative and other measures to achieve those ends. As a support to the order, the study attempted to promote the culture and linguistic identity of Laguna since it stated upon the resolution. Furthermore, it supports and reaches the goal of the dignified organization.

\section{OBJECTIVES}

The purpose of the study is to develop and validate an English Guide Book for Local Tourist Guides of Laguna.

Specifically, the researchers sought answers to the following questions;

1. What is the mean level of scores given by local tourist guides on the following aspects:
1.1 Usability
1.2 Consistency
1.3 Adaptability
1.4 Appropriateness
1.5 Aesthetic Value

2. What is the mean level of scores given by English experts in terms of:

2.1 Usability

2.2 Consistency

\subsection{Adaptability \\ 2.4 Appropriateness \\ 2.5 Aesthetic Value}

3 . Is there a significant in the rating among the tour guides and English experts based on the following criteria: usability, consistency, adaptability, appropriateness and aesthetic value?

\section{RELATED LITERATURE}

One of the significant variables in this study is the word handbook. It occupies an immense role in the learning process of individuals. People, particularly who are in the academe, look for references that will help them in acquiring knowledge on particular concepts that will also develop their skills. This serves as a guide and a tool for different purposes, In tourism, one of the goals of developing a handbook is for the tourist guides to learn and to communicate well not only in their locality but also mostly in the global community.

Woodhouse et. al. (2014) has made The ECU Referencing Guide which is regularly updated. Students are responsible for checking that the content of this document matches the latest version online. The guide follows the principles and examples given in the 6th edition of the Publication Manual of the American Psychological Association (2010), as well as the APA Style Guide to Electronic References (2012). These are subsequently referred to in this document as "APA 6th" and "Electronic References," respectively. The guide has been developed for undergraduate students and contains examples from commonly asked referencing questions.

Fergusson et. al (2012) states that as local governments face impacts from climate change, public health concerns, and public demand for increased accountability and transparency, it is becoming increasingly important to engage with the public on important sustainability topics. With over $75 \%$ of Americans now online, and $82 \%$ of them interacting with governments that do not participate in "digital engagement" tools. In fact, local government that do not participate in digital engagement risk remaining unaware of online mobilization, until it manifests at public meetings and other face-t-face events. The guidebook provides case studies and a step-by-step guide to support local government digital engagement efforts. Case studies included in the guidebook are very diverse, covering: small and large initiatives; projects intended to inform and empower; and, digital engagement that has been implemented for the many functions of local government, like governance, service provision, and specific initiatives and policies. 
Bauer (2007) develops a guidebook which parents can use to learn more about Nevada's Pre-K Standard and to help with guiding children as they develop social-emotional skills. He says that as a parent, one can use the handbook among many tools for getting a child ready for kindergarten and beyond.

Sher (2011) creates another guidebook purpose of which is to provides students, faculty, staff and international community partners with resources designed to provoke ethical reflection on international engagement and services learning projects. The EIESL project both challenge and nurtures the ways that people think, act, speak, and engage as global citizens committed to social and ecological justice.

LaFond (2012) compiled a guide which includes sources and collections to hat directly relate to Communication Studies, are multi-disciplinary in nature, or represent particular strengths of the collection. Selected unannotated monographs are included to exemplify broad categories and themes within Communication Studies at the Albany. Reference sources ("tertiary sources") assist researchers in locating primary and secondary resources related to their topics of choice. Print reference sources are typically found in the reference section of the library. Due to limitations of space in the reference area, many classic reference sources and important handbooks are shelved in the general stacks. Unless otherwise noted, sources listed in this guide are located at the University Library (uptown).

The biblical manuscripts found at Qumran, contends reflect a spectrum of text movement from authoritative scriptural traditions to completely new compositions. Treating six major groups of texts shows how differences in the texts result from a particular understanding of the work of the scribe-not only merely to copy but also to interpret, update, and make relevant the Scripture for the contemporary Jewish community of the time. This scribal practice led to texts that were "written" or "reworked" and considered no less important or accurate then the originals. Propounding a new theory of how these texts cohere as a group. Crawford offers an original and provocative work for readers interested in the Second Temple period. (Crawford, 2008)

Coles, Duval and Shaw (2013) write a comprehensive book which intends to take the stress and anxiety out of doing a dissertation in tourism studies and related disciplines. The Process is examined from the germination of an idea to the submission and assessment of the final document. Written primarily for students conducting independent research for the first time, the book offers simple advice and clear framework which students can adopt even in more advanced studies at masters and doctoral level. The book debunks popular myths, and aims to overcome common pitfalls. It focuses on the aim and objectives as the DNA of every dissertation. Rather than view it as a single, overwhelming project, the dissertation is presented as a series of more modest, manageable yet crucially inter-linked tasks that all students can successfully complete through careful preparation and effective time management.

Whitla (2009) made a comprehensive textbook, providing essential practical and analytical reading and writing skills for literature students at all levels. With advice and information on fundamental methods of literary analysis and research, Whitla equips students with the knowledge and tools essential for advanced literary study. It includes traditional close reading strategies integrated with newer critical theory, ranging from gender and genre to post-structuralism and post-colonialism ; with examples from Beowulf to Atwood, folk ballads to Fugard, and Christopher Marlowe to Conrad's Marlow, draws on a wide range of resources, from print to contemporary electronic media and supplies a companion website with chapter summaries, chart, examples, web links, and suggestions for further study.

Buzzard (2002) states in his book that in 1846 Baedeker introduce his famous 'star' rating (for sights, attractions and lodgings) - an idea based on the Murray guides star system. This edition was also his first 'experimental' red guide. He also decided to call his travel guides 'handbooks' following the example of John Murray III. Baedeker's early guide had tan covers, but from 1856 onwards, Murray's red bindings and gilt lettering became the familiar hallmark of all Baedker guides as well, and the content became famous for its clarity, detail and accuracy.

Chaney (2000) points out in his book that Grand Tour guidebooks poured off the presses throughout the eighteenth century, those such as Patrick Brydone's A Tour Through Sicily and Malta being read by many who never left England.

El Daly (2004) reveals that in the medieval Arab world, guide books for travelers in search of ancient Near Eastern artifacts, monuments and treasures were written by Arabic treasure hunters and alchemists. This was particularly the case in Arab Egypt, where ancient Egyptian antiquities were highly valued.

Gassan (2005) views that an important transitional figure from the idiosyncratic style of the Grand Tour travelogues to the more informative and impersonal guidebook was Mariana Starke. Her 1824 guide to travel in France and Italy served as an essential companion for British travelers to the Continent in the 
early 19th century. She recognized that with the growing numbers of Britons traveling abroad after 1815 the majority of her readers would now be in family groups and on a budget. She, therefore, included for the first time a wealth of advice of language, obtaining passports, the precise cost of food and accommodation in each city and even advice on the care of invalid family members. She also devised a system of !!!exclamation mark ratings, a forerunner of today's "stars". Her books, published by John Murray, served as a template for later guides.

With relevance to the above statements, the teacher -- made handbook will help not only the local tourist guides but as well as the tourists and residents to increase their knowledge through the use of the teacher made guide book.

The above statements explain how essential handbook is in the learning process of individuals, especially in learning lessons from the said references. This helps them to acquire new knowledge and be unfamiliar with the given examples.

A reference, reading text or material is a very important tool $\mathrm{n}$ once learning. It gives a lot of information in particular researches. In relation to this, guide book is also an example of such materials.

In all of these situations, Ivey (2010) says that it matters a lot. In this strategy - crazed era in literacy policy and practice, may be missing a more fundamental challenge identifying and making available texts that inspire students to learn new information. Good texts can bridge the gap between what students already know and the academic content they encounter in the classroom.

Even in the absence of published texts that students can relate to teachers can enable students to use literacy to make connections. Numerous studies prove that wide reading improves student's comprehension, background knowledge, vocabulary and fluency (Krashen 2004)

Bloom as cited by Villanueva (2014) states that the quality and quantity of instructional materials such as reading texts are important factors related to teaching and learning.

Capelin (2007) believes that reading is the main reason why people learn the language. In additional, the greatest tool we can give to the students for succeeding, not only in their education but more generally in life, is a large, rid vocabulary and the skills for using those words. Our ability to function in today's complex social and economic world is mightily affected by our language skills and world knowledge.

According to Javier (1999) as cited by Olsen (2005) the recognition of the importance of bringing children and books together has led to the continuing study of children's interest that can be seen in the changing nature of reading materials for children. The contents of current issued materials used by readers reflect more what research was revealed about children reading interest than the content of reading materials used in the past.

The above-mentioned literature supports the research since it acts as a reference, material or book that will help the users to learn more concepts through the use of guide books. Thus, it suggests that reading the teacher made material can enhance the communication skills of the tourist guides.

Neilsen (2004) define utility ash the ability of a system to meet the needs of the user. He does not consider this to be part of usability but a separate attribute of a system. If a product fails to provide utility then it does not offer the features and functions required; the usability of the product becomes superfluous as it will not allow the users to achieve their goals.

Likewise, the International Organization for Standardization (ISO) defines usability s the "Extent to which a product can be used by specified user to achieve specified goals with effectiveness, efficiency and satisfaction in a specified context of use.

According to Bosser (2001), the product attributes which contribute to usability include the style and properties of the interface, the dialogue structure, the nature of the functionality, and any other relevant properties such as system efficiency and reliability. Measures of attitude and performance provide the criteria which determine whether the design of the attributes is successful in achieving usability in the future, analytical techniques may be able to predict attitude and performance from these attributes.

Usability is the effectiveness, efficiency and satisfaction with which specific users can achieve a specific set of tasks in a particular environment. $39 \mathrm{In}$ essence, a system with good usability is easy to use and effective. It is intuitive, forgiving and with a minimum of mental effort. Tasks which can be performed by the software (such as data retrieval, organization, summary, cross-checking, calculating, etc.) are done in the background, improving accuracy and freeing up the user's cognitive resources or other tasks (Alafaireet et. al., 2009).

Federici and Borsci (2010) stated that usability is evaluated by the quality of communication (interaction) between a technological product (system) and a user (the one who uses that technological product). The unit of measurement is the user's behavior (satisfaction, comfort, time spent in performing an action, etc.) in a specific context of iuse (natural and virtual environment as well as the physical 
environment where communication between users and technological product takes places). The usability concept and its measurement are strictly connected to that of accessibility concept and its measurement are strictly connected to that of accessibility ("Web Accessibility"), and the space of the problem, shared by the users, in which the interaction takes places (user technology interaction).

Holzinger (2007) states that the usability of manuals can be improved by the use of the styles' guide, while optimizing the graphical layout of instructional details. Nevertheless, beside the use of general principle, instructions have to be adapted to specific task properties and to the cognitive process involved. Therefore, usability test has compared instruction modes in order to find optimal way to support different subtask during the work process.

Barnum (2011) says that the best-known definition of usability in one from ISO, the international Organization for Standardization (924211): 'the extent to which a product can be used by specific users to achieve specified goals with effectiveness, efficiency, and satisfaction in a specified context of use.

Thus, in the above statements it views usability as a very important variable in a product or output. With this, the usability of the handbook also has to be determined to prove its significance.

According to Alafaireet et. al (2009) external and internal consistency are important to the design of any application. External consistency primarily has to do with how much an application's structure, interactions and behaviors match a user's experience with other software applications. The more a user can apply prior experience to a new system, the lower the learning curve, the more effective their usage, and the fewer their errors. An internally consistent application uses concepts, behavior, appearance and layout consistently throughout. 30,46,49 Predictability is another important factor in enabling efficient use and reducing errors.

Van der Geest and Loorbach (2005) report a study that seeks to explore users' perceptions of internal consistency on Web sites. The internal consistency of an interface reflects the similarity among the features and graphics within an interface. They accomplish this exploration through a novel application of the card sorting technique. Van der Greest and Loorbach's study indicates that users do notice consistency within and across pages of a site. Users are prepared to and do notice and exploit some types of consistency within a Web system (color, navigation structure).
Bartlett, Jordan, and McAuliffe (2006) discuss the Definition (Consistency). A classification rule is said to be consistent for a certain distribution $\mathrm{P}$ of (X, $\mathrm{Y}$ ) if EDnR (fn) $->\mathrm{R} * \mathrm{~s} \mathrm{n}->$, and strongly consistent if $R(f n)->R *$ almost surely. Note that the definition of consistency of fn depends on the distribution $\mathrm{P}$ of (X, Y ). In general, a decision rule can be consistent for a certain family of distributions of (X, Y) but may not be consistent for others. since the distribution of $(\mathrm{X}, \mathrm{Y})$ is unknown in practice, it is desirable to have a rule that is consistent for a large family of distributions. (Bartlett, Jordan, and McAuliffe, 2006).

Argandoña (2008) stresses that the concept of consistency, applied to organizations, provides the common thread for a model of decision making that considerably enriches the models traditionally used in organization theory by adding a humanistic and ethical dimension. Extending the theory of human motivation to encompass a variety of motives, he states three conditions for long-term organizational wellbeing: effectiveness, efficiency and consistency. These three conditions are not independent of one another, nor can they be reduced to one another. Consistency plays a key role s a driver of trust in organizations and is a means of introducing ethics into management theory and practice.

The first and most straightforward definition of consistency is in epistemic terms. It is said that the beliefs are derived, by conditioning on their information, from consistent beliefs they held in a previous period, when their knowledge was still the same. Being consistent when the knowledge is the same means having the same beliefs. Thus, beliefs are consistent when they are derived from beliefs previously shared by the agents (Lehrer, Ehud and Dov Samet, 2013).

Critto (2000) consistency thus follows integration between what is represented ad what represents it, love of being and goodness; contribution to fulfilment by adjusting what is to what ought to be; and satisfaction with this and with its triumph. Consistency links together the boundless number of concepts, dimensions, and relations which define and explain each concrete case.

In media, publishing, and art, content is the information and experience(s) directed towards an enduser or audience (Odden, 2013).

Richardson (2009) states that to use tools effectively, teachers must have an essential understanding of the context and a logical sequence for teaching the topics. The framework becomes aid to learning and a way to activate students to learn, an instructional framework relationship among reading, thinking, and learning. The goal of good context 
reading instruction is to aid students in becoming autonomous learners in the well planned reading instruction that can prevent students from skipping important parts of a lesson, thus alleviating incomplete thinking learners.

Rach (2012) comments that a content strategy will often assume responsibility for the activities and derivable associated with each of those. In many cases, there are offline. They focus on an introduction to content strategy, so they made it as a job to size this information and frame it up in ways that content development and maintenance people have with specific needs an challenges that deserve to be acknowledged.

Fourie (2006) says that context literacy is not necessarily limited to specific communication media, because it focuses on those message elements that can be found in settings that involve interpersonal communication, small group communication, as well as mass communication and the internet. These content elements refer to topics, themes, values, ideologies, setting, objects, characters, narratives, and genres found in different texts. The content is manifestly accessible and can be broken down into smaller manageable units or codes, which for the purpose of both quantitative texts analyzed, use categories such as paragraphs, sentences and verbal phrases or categories and as technical sequence, scenes and individual camera shorts.

Pulakos, et. al. (2000) clarifies that adaptability means being flexible when things change. An adaptable person is one who open to new ideas and concepts, to working independently or as part of a team, and carrying out multiple tasks or projects. Someone is regarded as adaptable if he/she is able to manage multiple assignments and tasks, set priorities, and adapt to changing conditions and/or work assignments.

Adaptability has been defined in numerous ways in the sociological and economical literature. However, at the most basic level adaptability could be defined as an effective change in response to an altered situation. This definition presumes that to behave in an adaptable fashion, $\mathrm{n}$ individual must recognize the need to change based on some current or future perceived alteration in the environment and change his or her behavior as appropriate (Catsis et. al., 2015).

Teal and Street (2009) views that adaptability in health care means being skilled at integrating a patient's cultural values or beliefs into any encounter with the awareness and ability to adapt behaviors to maximize the patient's comfort, reconcile misunderstandings, and be responsive to the patient's needs.
Adaptability means there will be sufficient cooperation and communication to minimize risk of harm to the patient (Weller et. al, 2011).

As to Patten, Whitwrth et. Al (2015), adaptability has different IT-related definitions. Some include the change in the system to accommodate change in its environment, the ease of system/component modification, the modification of behavior in response to environment changes; and the adjustment to changing requirements. Adaptability is also a non-functional (software) requirement (NFR).

The adaptability of the multimedia instructional material is focused on evaluation and flexibility of the content, and can be managed by the teachers. It is working with the people from diverse background and interests (Burke and Pierce, 2006).

Adaptability is based on the training literature. Thus, literature argues adaptation is reflected on how well individuals generalize and transfer knowledge in performance transitional situations. (Baldwin and Ford, 2008).

According to Gronau (2005) the concept of adaptability has been widely recognized as research field in recent years. Adaptability as a technical research field has been established in the last decade. Mainly within the focus of factory planning, adaptability is considered as a goal to develop modular, adaptable factories. Among other factors that enable adaptive behavior, the explanation of adaptability of enterprise architecture is a complex task. The method presented applies a procedure which combines a criteria and scenario based process.

Drucker (2006) explicates that in management, effectiveness relates to getting the right things done. Peter Drucker reminds everyone that "effectiveness can and must be learned."

Fraser (2004) defines effectiveness as a measure of the match between stated goals and their achievement. It is always possible to achievement 'easy' low-standard goals. In other words, quality in higher education cannot only be a question of achievement 'outputs' but must also involve judgements about the goals (part of 'inputs')

West (2009) argues that: 'In relation to training, as opposed to education, one way of looking at the issue of effectiveness is in terms of whether there are 'identifiable economic outcomes. A broader definition still focuses on the extent to which training 'meets its objectives'. This is a useful definition since it is undoubtedly the funding body that ultimately decides whether or not training will be made available. Whilst the is a heuristic, there are two points to bear in mind. First, it is not always the case that the funders' precise objectives are transparent, although their general aims 
may be. Second, whilst the funders may have objectives, it is only by relating the extent to which these are perceived to have met- by various stakeholders (e.g. individuals, enterprises) - that one can really understand the extent to which the training has been effective. These may also be unintended consequences of training that aid an individual's employability - for example, improving 'soft skills' such as an individual's self-esteem, motivation or ability to work in a team.

Green and Glasglow (2006) define effectiveness as the impact in the outcomes and quality of life and Consistency of effects across subgroups. Effectiveness refers to the intervention's ability to do better than harm for the target population in a realworld setting. (Schiilinge, 2010).

Buettow et. al. (2007) considers appropriateness in health care and has been defined as 'the outcome of a process of decision=making that maximizes net individual health gain within society's available resources. This definition also implies that the patient's attitude is as important in deciding appropriateness as the reasoning that underpins it.

According to Fretzer (2007) appropriate conditions need to be examined in a frame of reference which goes beyond an individual speech act, communicative contribution or turn. For this reason, appropriateness has been assigned conditions co9ncerns as low such a linguistic artefact is created, and its analysis clarifies a specific relationship between illusionary act and context.

Bruner and Kruger (2000), on the concept of appropriateness could offer a variable short-term strategy for considering publicly held aesthetic and biodiversity values. Appropriateness refers to the judged suitability or compatibility of an introduce change, relative to one or more management goals.

Brady (2003) states that the aesthetic value proper covers the wide range of judgements people make, from finding something stunningly beautiful to finding something sublime, to finding something ugly with a lot variety in between.

We use the word aesthetic a great deal. Thar if adopted the aesthetic attitude, one would be in the same position to make correct aesthetic evaluation. The place aesthetic properties in the line with their most popular linguistic use: as offering a defense or a justification for a particular broad evaluative claim about a work or natural object/event. This also ties together aesthetic properties with the meaning of the work (Frenner, 2008).

Evaluation and validation must also be considered in the study of the researchers. This will facilitate that authenticity of the research. It is also necessary for the approval of the teacher-made handbook from the experts to determine its reliability.

Harmona (2002) cites the criteria for the evaluation of try- out materials developed by the UNICEF Curriculum Development project. They are; The material should cover the required learning competencies and lessons or activities must be provided to carry out the objectives. The objective should clear, attainable and measurable. There should be provision for appropriate evaluation activities with indicators for the degree attaining the learning competency. The attainment is suggested in each lesson which should be long enough for the users to cover the lesson or unit. In the field of texting the following should be considered: workability of activities sufficient content and activities, interest and variety in activities, value orientation of the material and appropriate content and approach.

As a defined by Salandanan 2005 as cited by Garantuza (2014), evaluation is a process of making judgements, that is how good one's performance or behavior is, based on a pre-determined value or standards that would indicate quality.

According to Bustos et. al (2006), evaluation means bringing together from different sources all forms of information on student performance. As mentioned by Burke (2003), evaluation is a step in the recursive process. Evaluation is the process of assessment, a step toward understanding and drawing conclusions. As to the given statement, the handbook will be given conclusions and understanding based on the evaluation which will be made through the help of the respondents in the validation of the teacher made module.

Therefore, the study is related to the given statements since the teacher-made hand book was validated by experts. They also analyzed and examined closely all the aspects of its development and evaluation

\section{METHODOLOGY}

The descriptive method of research was used in this study. According to Best and Kahn (2007), "The term descriptive research has often been used incorrectly to describe three types of investigation that are different from each other. Perhaps their superficial similarities have obscured their differences. Each of them employs the process of disciplined inquiry through the gathering and analysis of empirical data, and each attempt to develop knowledge. To be done completely, each requires the expertise of the careful and systematic investigator. A brief explanation may serve to put each one in proper perspective." The descriptive method was used to analyze the 
acceptability of the Practical English Handbook for Local Tourist Guide.

The principal aims in employing this method were to describe the nature of a situation as it exists at the time of the study and to explore the causes of particular phenomena. Data were subjected to the thinking process in terms of ordered reasoning.

Hence, this type of research design was used to know how valid the developed guide book on practical English for local tourist guides

\section{RESULTS AND DISCUSSIONS}

Mean Level of Scores given by the tourist escorts according to the Usability of the Practical English Handbook.

Taken into consideration, the developed handbook on the level of acceptability in terms o usability as per the first item "can be used by all the local tourist guide regardless of their gender, age, interest and the like", the raters gave3.90 as its and the $\mathrm{SD}$ of 0.80 which was interpreted as "Very Acceptable."

Meanwhile for the next query, which was "can be utilized by the local tourist guide in various types of conversation and settings," the raters gave a mean of 3.97 and 0.85 as its SD which was also interpreted as "Very Acceptable."

The third item "local tourist guides may use the handbook in various strategies, techniques, approaches and activities," it has been given an interpretation "Very Acceptable" with the mean of 3.87 and with the SD of 0.90 .

Table 1 on the next page shows the level of scores given by the local tourist guides focusing on the first criterion usability

Table 1. Mean Level of Scores given by the Local Tourist Guide to Usability

\begin{tabular}{|l|c|c|c|}
\hline \multicolumn{1}{|c|}{ Usability } & Mean & SD & Remarks \\
\hline $\begin{array}{l}\text { 1. The handbook can be used by all the local tourist guide } \\
\text { regardless of their gender, age, interest and the like. }\end{array}$ & 3.90 & 0.60 & Very Acceptable \\
\hline $\begin{array}{l}\text { 2. It can be utilized by the local tourist guide in various types of } \\
\text { conversation and settings. }\end{array}$ & 3.97 & 0.85 & Very Acceptable \\
\hline $\begin{array}{l}\text { 3. Local tourist guide may use the handbook in various strategies, } \\
\text { techniques, approaches and activities. }\end{array}$ & 3.87 & 0.90 & Very Acceptable \\
\hline 4. The handbook can be easily read by its users & 3.63 & 0.85 & Very Acceptable \\
\hline 5. It can be easily used at a certain time, place and condition & 3.87 & 0.78 & Very Acceptable \\
\hline Overall & 3.85 & 0.69 & Very Acceptable \\
\hline
\end{tabular}

Legend
Mean
4.21-5.00
$3.41-4.20$
$2.61-3.40$
$1.61-2.60$
$1.00-1.60$

Also, for the fourth item "can be easily read by its users, "indicates that it is "Very Acceptable" with the mean of 3.63 and SD of 0.85 .

The final number "can be easily used at a certain time, place and condition" had a mean of 3.87 and $\mathrm{SD}$ and $\mathrm{SD}=0.78$ still described as "Very Acceptable."

Finally, the over-all remarks for the first criteria, the local tourist guides got an over-all mean of 3.85 with a standard deviation of 0.69 of which meant that the practical English handbook was very usable. It also further indicates that all the items for the usability with the level of the scores given by the evaluators were very acceptable.

\section{Mean Level of Scores given by the Local Tourist Guides according to the Consistency of the Practical English Handbook}

Table 2 on the next page shows the level of scores given by the local tourist guides focusing on the criterion, consistency. Consistency thus follows integration between what is represented and what represents it, love of being and goodness, contribution to fulfillment by adjusting what is to what ought to be; 
and satisfaction with this and with its triumph. Consistency links together the boundless number of concepts, dimensions, and relation which define and explain each concrete case, (Critto, 2000).

According to www.mels.gouv.qc.ca. the elements to consider in the consistency of learning and the pedagogical approaches. These are all found in the practical English handbook for local tourist guides and reflected on the next table.

This table further, shows the mean level of the content validation of practical English hand criteria as consistency. The mean score of 2.13 and $\mathrm{SD}=0.86$ reveal that the evaluators rated the first item in consistency which states 'contents of the handbook are well organized" as "Very Acceptable."

Items 3 and which say vocabulary words, useful phrases, sentences and other significant terms are succinct and precise" and "bibliography agrees with the content of the teacher-made handbook" respectively were evaluated as "Very Acceptable" both with the same mean score of 3.93 and SD of 0.69 and 0.67 respectively.

Table 2. Mean Level of Scores given by the Local Tourist Guide to Consistency

\begin{tabular}{|c|c|c|c|c|}
\hline \multicolumn{2}{|l|}{ Consistency } & Mean & SD & Remarks \\
\hline \multicolumn{2}{|c|}{ 1. The contents of the handbook are well organized. } & 4.13 & 0.66 & Very Acceptable \\
\hline \multicolumn{2}{|c|}{$\begin{array}{l}\text { 2. Its contents are correct, appropriate and relevant with all of its } \\
\text { parts. }\end{array}$} & 4.00 & 0,69 & Very Acceptable \\
\hline \multicolumn{2}{|c|}{$\begin{array}{l}\text { 3. The vocabulary words useful phrases, sentences and other } \\
\text { significant terms are succinet and precise. }\end{array}$} & 3.93 & 0.69 & Very Acceptable \\
\hline \multicolumn{2}{|c|}{$\begin{array}{l}\text { 4. The bibliography agrees with contents of the teacher-made } \\
\text { handbook. }\end{array}$} & 3.93 & 0.87 & Very Acceptable \\
\hline \multicolumn{2}{|c|}{$\begin{array}{l}\text { 5. The pictures of illustrations being shown in the handbook are } \\
\text { accurate, clear, and match the given words. }\end{array}$} & 3.97 & 0.72 & Very Acceptable \\
\hline \multicolumn{2}{|c|}{ Overall } & 3.99 & 0.60 & Very Acceptable \\
\hline \multicolumn{5}{|l|}{ Legend } \\
\hline Mean & \multicolumn{4}{|l|}{ Verbal Interpretation } \\
\hline $4.21-5.00$ & \multicolumn{4}{|l|}{ Extremely Acceptable } \\
\hline $3.41-4.20$ & \multicolumn{4}{|l|}{ Very Acceptable } \\
\hline $2.61-3.40$ & \multicolumn{4}{|l|}{ Moderately Acceptable } \\
\hline $1.61-2.60$ & \multicolumn{4}{|l|}{ Slightly Acceptable } \\
\hline $1.00-1.60$ & \multicolumn{4}{|l|}{ Not Acceptable } \\
\hline
\end{tabular}

The computed mean the score of 4.00 or the second entry which is the item that says "content is correct, appropriate and relevant with all of its parts" and its $\mathrm{SD}=0.69$ were rated as "Very Acceptable."

The final number "pictures or illustration being shown in the handbook are accurate, clear, and match the given words" had the mean of 3.97 and $\mathrm{SD}=0.72$ described as Very Acceptable.'

As shown in the table, the local tourist guides gave the over-all mean of 4.69. Very consistent was further interpreted as extremely acceptable in terms of consistency.

\section{Mean Level of Scores given by the tourist escorts according to the Adaptability of the Practical English Handbook}

Table 3 shows the level scores given by the local tourist guides focusing on the criterion, adaptability. In the table rating for the adaptability clearly evidences item 1 with a description of local tourist guide may use the handbook as a references or tool in acquiring knowledge aligned with tourism was evaluated as "Very Adaptable" bearing the mean score of 4.10 and SD of 0.60 . 
ISSN (Online): 2455-3662

EPRA International Journal of Multidisciplinary Research (IJMR) - Peer Reviewed Journal Volume: 7 | Issue: 4 | April 2021|| Journal DOI: 10.36713/epra2013 || SJIF Impact Factor 2021: 8.047 || ISI Value: 1.188

Table 3. Mean Level of Scores given by the Local Tourist Guide to Adaptability

\begin{tabular}{|l|c|c|c|}
\hline Adaptability & Mean & SD & Remarks \\
\hline $\begin{array}{l}\text { 1The local tourist guide may use the handbook as a reference or } \\
\text { tool in acquiring knowledge signed with tourist }\end{array}$ & 4.10 & 0.80 & Very Acceptable \\
\hline $\begin{array}{l}\text { 2. The local tourist guides may use the handbook as a reference or } \\
\text { tool in acquiring knowledge aligned with their needs. }\end{array}$ & 4.03 & 0.85 & Very Acceptable \\
\hline $\begin{array}{l}\text { 3. It may use in learning different topics with relevance to the } \\
\text { nature of work of the users. }\end{array}$ & 4.00 & 0.95 & Very Acceptable \\
\hline $\begin{array}{l}\text { 4. The local tourist guides can make new, innovative and } \\
\text { competitive strategies through this. }\end{array}$ & 3.93 & 0.78 & Very Acceptable \\
\hline $\begin{array}{l}\text { 5. The teacher made handbook can help and motivate the local } \\
\text { tourist guides with relevance to the use of English language and } \\
\text { facilitate new way of learning in the work environment. }\end{array}$ & 4.17 & 0.79 & Very Acceptable \\
\hline Overall & 4.05 & 0.67 & Very Acceptable \\
\hline
\end{tabular}

Legend

$\begin{array}{ll}\text { Mean } & \text { Verbal Interpretation } \\ 4.21-5.00 & \text { Extremely Acceptable } \\ 3.41-4.20 & \text { Very Acceptable } \\ 2.61-3.40 & \text { Moderately Acceptable } \\ 1.61-2.60 & \text { Slightly Acceptable } \\ 1.00-1.60 & \text { Not Acceptable }\end{array}$

In the meantime, the second noting "local tourist guides may use the handbook as a reference or tool in acquiring knowledge aligned with their needs" had the computed mean of 4.03 and 0.85 as its SD as "Very Adaptable."

The remaining item quoted as, "may be used in learning different topics with relevance to the nature of work of the users" and "local tourist guides can make new, innovative strategies through this" were assessed as "Very Acceptable" obtaining different mean scores of 4.00 and 3.93 and different SDs of 0.95 and 0.78 respectively.

The over-all mean of 4.05 and $\mathrm{SD}=0.67$ signifying the range scores given by the evaluators was close to each other, hence, indicated that the mean level of score given by the local tourist guides to the handbook, according gto it content of adaptability is Very Acceptable."

As taken from Merriam-Webster (2003) adaptability means being able to change or to be changed in order or be adapted. That is why the researcher had chosen adaptability as its third criterion for he believed that a handbook should possess the characteristic of being adaptable with the different kinds of users.

The results from the above data only proves that the acceptability of the developed handbook in terms of its adaptability is very adaptable for the raters and for the possible users as well.

\section{Mean Level of Scores given by the Tourist escorts according to the Appropriateness of the Practical English Handbook}

Table 4 shows the level of scores given by the local tourist guides focusing on the first criterion, appropriateness. The result of the developed handbook on level of scores given by the local tourist guides in terms of appropriateness as per the first item "support the needs of the local tourist guides with relevance to communication and conversational English", was 3.90 as its mean and the SD of 0.71 interpreted as "Very Adaptable." 
ISSN (Online): 2455-3662

EPRA International Journal of Multidisciplinary Research (IJMR) - Peer Reviewed Journal Volume: 7 | Issue: 4 | April 2021|| Journal DOI: 10.36713/epra2013 || SJIF Impact Factor 2021: 8.047 || ISI Value: 1.188

Table 4. Mean Level of Scores given by the Local Tourist Guide to Appropriateness

\begin{tabular}{|l|c|c|c|}
\hline Appropriateness & Mean & SD & Remarks \\
\hline $\begin{array}{l}\text { 1It supports the needs of the local tourist guides with relevance to } \\
\text { communication and conversational English. }\end{array}$ & 3.90 & 0.71 & Very Acceptable \\
\hline 2. The content matches with its objectives in all chapters. & 4.00 & 0.74 & Very Acceptable \\
\hline 3. It contributes to the goals and objectives of the tourism. & 4.17 & 0.91 & Very Acceptable \\
\hline $\begin{array}{l}\text { 4. The handbook is essential and significant to the promotion of } \\
\text { tourism in Panguil through its Panguil River Eco Park. }\end{array}$ & 4.43 & 0.68 & Very Acceptable \\
\hline $\begin{array}{l}\text { 5. It is helpful to the local tourist guides who work in Panguil River } \\
\text { Eco Park. }\end{array}$ & 2.50 & 0.68 & Very Acceptable \\
\hline Overall & 4.20 & 0.60 & Very Acceptable \\
\hline
\end{tabular}

Legend

Mean Verbal Interpretation

4.21-5.00 Extremely Acceptable

3.41-4.20 Very Acceptable

2.61-3.40 Moderately Acceptable

1.61-2.60 Slightly Acceptable

1.00-1.60 Not Acceptable

Meanwhile for the next query, which is "content matches with its objectives in all chapters, "the raters gave mean of 4.00 and 0.74 as its SD which was also interested as "Very Adaptable."

For the third items "contributes to the goals and objectives of the tourism," it has been given an interpretation "Very Acceptable" with the mean of 4.17 and with a SD of 0.91 .

The fourth and last item "handbook is essential and significant to the promotion of tourism in Laguna" and "helpful to the tourist escorts who work in the tourism industry" it had different means of 4.43 and 4.50 but with the same $\mathrm{SD}=0.68$ both desc4ribed as "Extremely Acceptable."

\section{Mean Level of Scores given by the tourist escorts according to the Value of the Practical English Handbook.}

Table 5 reveals the mean level of validation to its content validity criterion as to aesthetic value. This section gauges the packaging and over-all appearance of the handbook. This covers the colors, textures, text size, illustration, space workability and the like.

As evident with pieces 1 and 2 with the description "contains icons that are visually-pleasing and easy to understand" and "possible users of the handbook will appreciate the output based on its appearance and overall content". local tourist guides gave "Very Adaptable" with the same mean scores of both 4.03 and different SDs of 0.85 and 0.72 respectively.

Table 5. Mean Level of Scores given by the Local Tourist Guide to Aesthetic Value

\begin{tabular}{|l|c|c|c|}
\hline Aesthetic Value & Mean & SD & Remarks \\
\hline $\begin{array}{l}\text { 1. The teacher - made handbook contains icons that are visually- } \\
\text { pleasing and easy to understand }\end{array}$ & 4.03 & 0.85 & Very Acceptable \\
\hline $\begin{array}{l}\text { 2. Possible users of the handbook will appreciate the output } \\
\text { based on the appearance and over all content. }\end{array}$ & 4.03 & 0.72 & Very Acceptable \\
\hline $\begin{array}{l}\text { 3. The handbook makes use of illustrations which are interesting } \\
\text { and suited to the lessons. }\end{array}$ & 4.00 & 0.64 & Very Acceptable \\
\hline 4. The handbook uses appropriate text font, size and type. & 3.93 & 0.83 & Very Acceptable \\
\hline $\begin{array}{l}\text { 5. It contains visuals that fit the level of interests, knowledge and } \\
\text { skills of the target learners. }\end{array}$ & 3.90 & 0.80 & Very Acceptable \\
\hline Overall & 3.98 & 0.63 & Very Acceptable \\
\hline
\end{tabular}


Legend
Mean
4.21-5.00
$3.41-4.20$
$2.61-3.40$
$1.61-2.60$
$1.00-1.60$

Line item 3, "makes use of illustrations which are interesting and suited to the lessons" was assessed as "Very Acceptable" with mean score of 4.00 and $\mathrm{SD}=0.64$. While article 4, which states "uses appropriate tent font, size and type" obtained 3.93 as its mean score $\mathrm{SD}=0.83$ with a comment of "Extremely Acceptable"

The final number "contain visual that fit the level of interest, knowledge and skills of the target learners" had the mean of 3.90 and $\mathrm{SD}=0.80$ described as "Very Acceptable"

The over-all mean score of 3.98 and SD which is equivalent to 0.63 proved that the evaluators rated the practical English Handbook as "Very Acceptable" as to its content validity of aesthetic value.

The result was supported by suggestion of Javier (2003) that an instructional material must contain illustration, explanation and drawing to sustain the interest of the students.

\section{Mean Level of Scores given by the English Experts according to the Usability of the Practical English handbook}

Table 6 on the next page shows the level of scores given to the English Experts focusing on the first criterion, usability.

Taken into consideration, the developed handbook on level of acceptability in terms of usability as per the first item "can be uses by all the local tourist guides regardless of their gender, age, interest and like", the raters gave 4.10 as the mean an the SD of 0.74 which was interpreted as "Very Acceptable"

Meanwhile for the next query, which is "can be utilized by the local tourist guides in various types of conversation and settings," the raters gave a mean of 4.40 and 0.52 as its SD which was also interpreted as "Very Acceptable"

For the third, fourth and the last item "local tourist guides may use the handbook in various strategies, techniques, approaches and activities," "can be easily read by its users," and "can be easily used at a certain time, place and condition" all had a mean of 4.50 which indicates that it was "Extremely Acceptable" with the same SD of 0.90 .

Table 6. Mean Level of Scores given by the English Experts to Usability

\begin{tabular}{|l|c|c|c|}
\hline Usability & Mean & SD & Remarks \\
\hline $\begin{array}{l}\text { 1. The handbook can be used by all the local tourist guides } \\
\text { regardless of their gender, age, interest and the like. }\end{array}$ & 4.10 & 0.74 & Very Acceptable \\
\hline $\begin{array}{l}\text { 2. It can be utilized by the local tourist guides in various types of } \\
\text { conversation and settings. }\end{array}$ & 4.40 & 0.52 & Very Acceptable \\
\hline $\begin{array}{l}\text { 3. Local Tourist guides use the handbook in various strategies, } \\
\text { techniques, appropriateness and activities. }\end{array}$ & 4.50 & 0.71 & Very Acceptable \\
\hline 4. The handbook can be easily read by its users. & 4.50 & 0.71 & Very Acceptable \\
\hline 5. It can be easily used at a certain time, place and condition. & 4.50 & 0.71 & Very Acceptable \\
\hline Overall & 4.40 & .59 & Very Acceptable \\
\hline
\end{tabular}

Legend

Mean Verbal Interpretation

4.21-5.00 Extremely Acceptable

3.41-4.20 Very Acceptable

2.61-3.40 Moderately Acceptable

1.61-2.60 Slightly Acceptable

1.00-1.60 Not Acceptable 
Thus, the over-all remarks for the first criteria the English experts got the over-all mean of 4.40 with standards deviation of 0.59 of which meant that the practical English handbook was very usable. It also further indicates that all the items for the usability with the level of the scores given by the English experts were "Extremely Adaptable".

\section{Mean Level of Scores given by the tourist escorts according to the Consistency of the Practical English Handbook.}

Table $7 \mathrm{n}$ the next page shows the level of scores given by the English experts on the criterion, consistency.

Table 7 shows the level of the practical English handbook for local tourist guides in terms of consistency. This table, further, shows the mean level of the content validation of handbook criteria as to consistency.

The mean score of 4.50 and $\mathrm{SD}=0.63$ reveal that the evaluators rated the first item in consistency which "contents $f$ the handbook are well organized" as "Extremely Acceptable."

Table 7. Mean Level of Scores given by the English Experts to Consistency

\begin{tabular}{|l|c|c|c|}
\hline Consistency & Mean & SD & Remarks \\
\hline 1. The contents of the handbook are well organized. & 4.50 & 0.53 & Very Acceptable \\
\hline $\begin{array}{l}\text { 2. Its content is correct, appropriate and relevant with all of its } \\
\text { parts. }\end{array}$ & 4.40 & 0.52 & Very Acceptable \\
\hline $\begin{array}{l}\text { 3. The vocabulary words useful phrases, sentences and other } \\
\text { significant terms are succinct and precise. }\end{array}$ & 4.20 & 0.79 & Very Acceptable \\
\hline $\begin{array}{l}\text { 4. The bibliography agrees with the content of the teacher-made } \\
\text { handbook. }\end{array}$ & 4.20 & 0.79 & Very Acceptable \\
\hline $\begin{array}{l}\text { 5. The pictures or illustrations being shown in the handbook are } \\
\text { accurate, clear, and matching the given words.. }\end{array}$ & 4.50 & 0.53 & Very Acceptable \\
\hline Overall & 4.36 & 0.41 & Very Acceptable \\
\hline $\begin{array}{l}\text { Legend Mean } \\
4.21-5.00\end{array}$ & & & \\
$3.41-4.20$ & $\begin{array}{l}\text { Verbal Interpretation } \\
2.61-3.40\end{array}$ & & \\
$1.61-2.60$ & $\begin{array}{l}\text { Very Acceptable } \\
\text { Moderately Acceptable } \\
\text { Slightly Acceptable } \\
\text { Not Acceptable }\end{array}$ & & \\
&
\end{tabular}

The computed mean score 4.40 for the second entry which item says "content is correct, appropriate and relevant with all of its parts." and its $\mathrm{SD}=0.52$ were rated as "Very Acceptable."

Items 3 and $4 \mathrm{~b}$ which say "vocabulary words, useful phrases, sentences and other significant items are succinct and precise" and bibliography agrees with the content of the teacher-made handbook "respectively were evaluated as "Extremely Acceptable" both the same mean score of 4.20 and same SD 0f 0.79 .

The final number "pictures or illustrations being shown in the handbook are accurate, clear, and matching the given words" had the mean of4.50 and $\mathrm{SD}=0.53$ described as "Extremely Acceptable.'

As shown in the table, the English experts gave the over-all mean of 4.36 and $\mathrm{SD}=\mathrm{D}, 3=41$. Very consistent was further interpreted as "Extremely Acceptable.' in terms of consistency.

\section{Mean Level Scores given by the English Experts according to the Adaptability of the Practical English Handbook}

Table 8 on the next page shows the level of scores gi9ven by the English experts focusing on the next criterion, adaptability. This shows the mean level of scores given by the English experts according to its content criterion of adaptability. In the table , ratings for adaptability clearly evidence that the items 1 and 2 stating that "local tourist guides may use the handbook as a reference or tool in acquiring knowledge aligned with tourism" and "local tourist guides may use the handbook as a reference or tool in acquiring knowledge aligned with their needs" were both evaluated as 
"Extremely Adaptable" bearing the same mean score of 4.30 and SD of 0.48 .

In the meantime, the third noting "maybe used in learning different topics with relevance to the nature of work of users "had the computed mean of 4.00 and 0.69 as its SD taken as "Extremely Acceptable."

The remaining item quoted as "local tourist guides can make new, innovative and competitive strategies through this" was assessed as "Extremely Acceptable."

The remaining item quoted as "local tourist guides can make new, innovative and competitive strategies through this" was assessed as "Extremely Acceptable" obtaining different mean score of 4.40 and SD of 0.52 .

Table 8. Mean Level of Scores given by the English Experts to Adaptability

\begin{tabular}{|l|c|c|c|}
\hline Adaptability & Mean & SD & Remarks \\
\hline $\begin{array}{l}\text { 1. The local tourist guides may use the handbook as a reference or } \\
\text { tool in acquiring knowledge aligned with tourism. }\end{array}$ & 4.30 & 0.48 & Very Acceptable \\
\hline $\begin{array}{l}\text { 2. The local tourist guide may use the handbook as a reference or } \\
\text { tool in acquiring knowledge aligned with their needs. }\end{array}$ & 4.30 & 0.48 & Very Acceptable \\
\hline $\begin{array}{l}\text { 3. It may be used in learning different topics with relevance to } \\
\text { thhe nature of work of the users. }\end{array}$ & 4.00 & 0.67 & Very Acceptable \\
\hline $\begin{array}{l}\text { 4. The local tourist guides can make new, innovative and } \\
\text { competitive strategies through this. }\end{array}$ & 4.40 & 0.52 & Very Acceptable \\
\hline 5. & 4.20 & 0.42 & Very Acceptable \\
\hline Overall & 4.24 & 0.41 & Very Acceptable \\
\hline
\end{tabular}

Legend
Mean Verbal Interpretation
4.21-5.00
$3.41-4.20$
$2.61-3.40$
$1.61-2.60$
$1.00-1.60$

The last item "can help and motivate the local tourist guides with relevance to the use of the English language and facilitate new way of learning in the work environment was found "Extremely Acceptable" obtaining a mean score of 4.20 and SD 0.20.

The over-all mean of 4.20 and SD of 0.41 signifying the range score given by the English experts to the handbook, according to its content criterion of adaptability is "Extremely Acceptable."

\section{Mean Level of Scores given by the English Experts according to the Appropriateness of the Practical English Handbook}

Table 9 shows the level of scores given by the English experts focusing on the criterion, appropriateness.

Table 9. Mean Level of Scores given by the English Experts to Appropriateness

\begin{tabular}{|l|c|c|c|}
\hline Appropriateness & Mean & SD & Remarks \\
\hline $\begin{array}{l}\text { 1. It supports the needs of the local tourist guides with relevance } \\
\text { to communication and conversational English. }\end{array}$ & 4.40 & 0.52 & $\begin{array}{c}\text { Extremely } \\
\text { Acceptable }\end{array}$ \\
\hline 2. The content matches with its objectives in all chapters. & 4.20 & 0.79 & $\begin{array}{c}\text { Extremely } \\
\text { Acceptable }\end{array}$ \\
\hline 3. It contributes to the goals and objectives of the tourism. & 4.20 & 0.79 & $\begin{array}{c}\text { Extremely } \\
\text { Acceptable }\end{array}$ \\
\hline $\begin{array}{l}\text { 4. The handbook is essential and significant to the promotion of } \\
\text { tourism in Panguil through its PREP }\end{array}$ & 4.30 & 0.48 & $\begin{array}{c}\text { Extremely } \\
\text { Acceptable }\end{array}$ \\
\hline $\begin{array}{l}\text { 5. It is helpful to the local tourist guides who work in Panguil, } \\
\text { Laguna and PREP }\end{array}$ & 4.40 & 0.52 & $\begin{array}{c}\text { Extremely } \\
\text { Acceptable }\end{array}$ \\
\hline Overall & 4.30 & 0.49 & $\begin{array}{c}\text { Extremely } \\
\text { Acceptable }\end{array}$ \\
\hline
\end{tabular}


Legend
Mean
4.21-5.00
$3.41-4.20$
2.61-3.40
$1.81-2.60$
$1.00-1.80$

\author{
Verbal Interpretation \\ Extremely Acceptable \\ Very Acceptable \\ Moderately Acceptable \\ Slightly Acceptable \\ Not Acceptable
}

Table 9 shows results of the developed handbook on level of scores given by the English experts in terms of appropriateness as per the first item "supports the needs of the local tourist guides with relevance to communication and conversational English", the raters gave 4.40 as its mean and the SD of 0.52 which was interpreted as "Extremely Acceptable."

Meanwhile for the next queries, which are "content matches with its objectives in all chapter" and "contributes to the goals and objectives of tourism", the raters gave a mean of 4.20 and 0.79 as its SD were also interpreted as "Extremely Acceptable".

The fourth item "essential and significant to the promotion of tourism in Panguil through its Panguil River Eco Park" had a mean of 4.03 , its $\mathrm{SD}=0.48$ described as "Extremely Acceptable".

The last item "helpful to the local tourist guides who work in Pangil, Laguna and Panguil River Eco Park" had a mean of 4.40 and $\mathrm{SD}=0.52$ described as "Extremely Acceptable".

Finally, the over-all remarks for the criteria, the English experts got an over-all mean of 4.30 with standard deviation of 0.49 which the practical English handbook was very appropriate. It also further indicates that the items for the appropriateness with the level of the scores given by the evaluators were "Extremely Acceptable".

Table 10. Mean Level of Scores given by the English Experts to Aesthetic Value

Table 10. Mean Level of Scores given by the English Experts to Aesthetic Value
\begin{tabular}{|r|c|c|c|}
\hline Aesthetic Value & Mean & SD & Remarks \\
\hline $\begin{array}{r}\text { The teacher - made handbook contains icons that are } \\
\text { visually-pleasing and easy to understand }\end{array}$ & 4.50 & 0.53 & $\begin{array}{c}\text { Extremely } \\
\text { Acceptable }\end{array}$ \\
\hline $2 . \quad \begin{array}{l}\text { Possible users of the handbook will appreciate the } \\
\text { output based on its appearance and overall content. }\end{array}$ & 4.50 & 0.53 & $\begin{array}{c}\text { Extremely } \\
\text { Acceptable }\end{array}$ \\
\hline $\begin{array}{l}\text { The handbook makes use of illustrations which are } \\
\text { interesting and suited to the lessons. }\end{array}$ & 4.30 & 0.48 & $\begin{array}{c}\text { Extremely } \\
\text { Acceptable }\end{array}$ \\
\hline $4 . \quad \begin{array}{l}\text { The handbook uses appropriate text font, size and } \\
\text { type. }\end{array}$ & 4.30 & 0.48 & $\begin{array}{c}\text { Extremely } \\
\text { Acceptable }\end{array}$ \\
\hline $\begin{array}{l}\text { It contains visuals that fit the level of interests, } \\
\text { knowledge and skills of the target learners. }\end{array}$ & 4.40 & 0.52 & $\begin{array}{c}\text { Extremely } \\
\text { Acceptable }\end{array}$ \\
\hline Overall & 4.40 & 0.46 & $\begin{array}{c}\text { Extremely } \\
\text { Acceptable }\end{array}$ \\
\hline
\end{tabular}

\section{Mean Level of Scores given by the English Experts according to the Aesthetic Value of the Practical English Handbook}

Table 10 shows the level of scores given by the English experts focusing on the first criterion, usability.

Table 10 on the next page reveals the mean level of validation to its criterion as to aesthetic value. This section gauges the packaging and over-all appearance of the handbook. This covers the colors, textures, text size, illustration, space workability and the like.

As evident with pieces 1 and 2 with the description "contains icons that are visually pleasing and easy to understand" and "possible users of the handbook will appreciate the output based on its appearance and overall content", English experts gave "Extremely Acceptable" with the same mean score of both 4.50 and SDs of 0.53 . Line item 3 "makes use of illustrations which are interesting and suited to the lessons" and item 4 which states "uses appropriate text font, size and type" both obtained 4.30 as its mean score and $\mathrm{SD}=0.48$ with a comment of "Extremely Acceptable". 
Legend

$\begin{array}{ll}\text { Mean } & \text { Verbal Interpretation } \\ 4.21-5.00 & \text { Extremely Acceptable } \\ 3.41-4.20 & \text { Very Acceptable } \\ 2.61-3.40 & \text { Moderately Acceptable } \\ 1.61-2.60 & \text { Slightly Acceptable } \\ 1.00-1.60 & \text { Not Acceptable }\end{array}$

The final number "contains visuals that fit the level of interests, knowledge and skills of the target learners" had the mean of 4.40 and $\mathrm{SD}=0.52$ described as "Extremely Acceptable".

The over-all mean score of 4.40 and SD which is equivalent to 0.46 proved that the English experts rated the practical English Handbook as "Extremely Acceptable" as to its content validity of aesthetic value.

Significant Difference between the Ratings among the Local Tourist Guides and English Experts Based on Usability

Table 11 shows the significance difference between the ratings of the local tourist guides and English experts based on usability

Table 11. Significant Difference between the Ratings among the tourist escorts and English Experts Based on Usability

\begin{tabular}{|l|c|c|c|c|c|}
\hline \multicolumn{1}{|c|}{ Group } & Mean & Diff & T & P & Remarks \\
\cline { 1 - 3 } English Experts & 4.400 & & & & \\
\cline { 1 - 4 } & 3.847 & 0.553 & 2.46 & 0.024 & Significant \\
\hline
\end{tabular}

The table above shows the significant difference on the rating among the local tourist guides and English experts based on the usability. Experts with the mean of 4.400 have significantly higher rating than of the local tourist guides with the mean of 3.847 at 0.05 level of significance.

This has similarity with the study of Garantuza (2015). He states and clarifies that when it comes to usability of the developed module, there is significant difference between the ratings of the evaluators. On the other hand, as to the study of Crisostomo (2015), usefulness is found not significant

In the difference in the evaluation of the characteristics of the module among the different groups of evaluators.

\section{Significant Difference between the Ratings among the Local Tourist Guides and English Experts Based on Consistency.}

Table 12 shows the significance difference on the rating among the local tourist guides and English experts based on consistency.

The table shows the significant difference between the rating of the local tourist guides and English experts based on the consistency. Experts with the mean of 4.360 have significantly higher rating than local tourist guides with the mean of 3.993 at 0.05 level of significance.

Table 12. Significant Difference between the Ratings between the Local Tourist Guides and English Experts Based on Consistency.

\begin{tabular}{|l|l|l|l|l|l|}
\hline \multicolumn{1}{|c|}{ Group } & Mean & Diff & T & P & Remarks \\
\cline { 1 - 2 } English Experts & 4.360 & 0.367 & 2.16 & \multirow{2}{*}{0.042} & Significant \\
\cline { 1 - 5 } Local Tourist Guides & 3.993 & & & & \\
\hline
\end{tabular}

This has relevance to the study of Navia (2015) wherein the items as "to work texts external aspect is dependable on its internal or vice versa" found out that the two expert groups had difference in their ratings, expert 1 got extremely acceptable and expert 2 had very acceptable.

Significant Difference of the Ratings of the Local Tourist Guides and English Experts Based on Adaptability 
Table 13 shows the significanct difference of the ratings between the tourist escorts and English experts based on adaptability.

\begin{tabular}{|l|c|c|c|c|c|}
\hline \multicolumn{1}{|c|}{ Group } & Mean & Diff & $\boldsymbol{T}$ & P & Remarks \\
\cline { 1 - 2 } English Experts & 4.240 & 0.193 & 1.08 & 0.289 & Not Significant \\
\hline Local Tourist Guides & 4.047 & & 0.04
\end{tabular}

There is no significant difference between the ratings of the experts and local tourist guides with regard to adaptability with a mean of 4.240 and 4.047 respectively at 0.05 level of significance.
Significant Difference between the Ratings of the tourist escorts and English Experts Based on Appropriateness.

Table 14 shows the significant difference between the ratings of the local tourist guides and English experts based on the appropriateness.

Table 14. Significant Difference between the Ratings of the Local Tourist Guides and English Experts Based on Appropriateness.

\begin{tabular}{|l|c|c|c|c|c|}
\hline \multicolumn{1}{|c|}{ Group } & Mean & Diff & T & P & Remarks \\
\cline { 1 - 3 } English Experts & 4.300 & 0.100 & 0.53 & 0.605 & Not Significant \\
\cline { 1 - 5 } Local Tourist Guides & 4.200 &
\end{tabular}

There is no significant difference between the ratings of the English experts and the local tourist guides in terms of appropriateness. This is very evident with the mean of 4.300 given by the experts and 4.200 given by the tourist guides at 0.05 level of significance.

\section{Significant Difference between the Ratings of the tourist escorts and English Experts Based on Aesthetic Value.}

Table 15 shows the significant difference between the ratings of the local tourist guides and English experts based on aesthetic value. Experts with the mean of 4.400 have significantly higher rating than that of the local tourist guides with the mean of 3.980 at 0.05 level of significance.

Table 15. Significant Difference between the Ratings of the tourist escorts and English Experts Based on Aesthetic Value

\begin{tabular}{|l|c|c|c|c|c|}
\hline \multicolumn{1}{|c|}{ Group } & Mean & Diff & T & P & Remarks \\
\cline { 1 - 5 } English Experts & 4.400 & 0.420 & 2.26 & 0.035 & Significant \\
\hline Local Tourist Guides & 3.980 & &
\end{tabular}

The findings were supported by Garantuza (2015) who also showed that the significant result on his developed module since the teacher-evaluators found the module in teaching listening very usable, significant differences were noted among their ratings. The ratings given by the teacher-evaluators with regard to consistency, adaptability, appropriateness and aesthetic value were extremely acceptable and no significant differences were noted.

In contrast, the study of Badillo (2015) showed significant result as the developed vocabulary enhancer 7 in terms of usability, consistency, adaptability, appropriateness and aesthetic value since all the given data had resulted to no significant difference on the ratings of the evaluators and found to be higher than the value of all Pearson correlation at the level of significance at 0.05 or (all p's $<0.05$ )

\section{CONCLUSIONS AND RECOMMENDATIONS}

In view of the aforementioned findings, the study has drawn the following conclusions:

1. The level of acceptability of the practical English handbook for tourist escorts in terms of usability, consistency, and aesthetic value is very acceptable while adaptability and appropriateness is extremely acceptable.

2. Although the tourist escorts and English expert found the practical English handbook very usable, consistent and visually-pleasing, significant differences were noted among their ratings. The ratings given by the evaluators with regard to adaptability were very acceptable and no significant difference were noted. And the ratings given by the 
Evaluators with regard to appropriateness were very acceptable and also no significant differences were noted.

The hypothesis that there is no significant difference among the evaluators' ratings on the handbook in terms of usability, consistency, adaptability, appropriateness and aesthetic value is partly supported.

In the light of the foregoing findings and conclusions of this study, the following recommendations are offered:

1. The tourist escorts in nearby provinces can use the developed practical English handbook as approved by the Municipalities and recommended by the English experts.

2. English teachers may revise, modify and reconstruct practical English handbook in the future depending on the needs of the local tourist guides.

3. Future researchers can further validate the handbook by using it in tourist escorts provided that the results of evaluation are taken into consideration.

4. English teachers can develop handbooks as supplementary material focusing not only on education but also on the different fields such as tourism, business, and the like.

5. The teacher-made handbook may be used for other related studies such as conducting seminars or training for tourist escorts to develop their English language skills.

6. English teachers may give emphasis to developing handbooks and instructional materials. Therefore, English teachers may attend seminars and training programs regarding this skill.

\section{LITERATURE CITED}

1. Barnum, C. M. (2011.) Usability Testing Essentials. Ready, Set. Test! Elsevier Publishing Inc.

2. Bartlett, Jordan, and McAuliffe (2006). Convexity, classification, and risk bound, JASA

3. Bauer, Kari S. (2007). Guidebook for Families Social Studies. Nevada's Pre-Kindergarten Standards CFLE In cooperation with the Nevada State Department of Education and State of Nevada Office of Early Care \& Education.

4. Bösser, T. (2001). Techniques for Predicting Usability. Bullinger.

5. Brady, E. (2003). Aesthetic of the Natural Environment., Edinburgh University Press Ltd. 22 George Square, Edinburgh.

6. Bruner, B. W. \& Kruger, L. E. (2000). Defining Social Acceptability in Ecosystem, Management: a Workshop Proceedings., Kelso WA Gen. Tech. Rep. $369 . \quad$ Portland, OR; US Publishing Inc.
7. Buetow, S. A., Sibbald, B., Cantrill, J. A. and Halliwell S. (2007). Appropriateness in Health Care: Application to Prescribing.

8. Burke, C.S. Pierce, L. G. \& Salas, E. (2006). Understanding Adaptability: A Prerequisite for Effective Performance within Complex, British Library Cataloguing in Publication Data.

9. Burke J. (2003). The English Teacher's Companion Second Edition, Northwest Regional Educational Laboratory.

10. Bustos, A.S. et al. (2006). Psychological, anthropological and Sociological Foundations of Education, Revised Edition II, published by Katha Publishing Co. Inc.

11. Buzzard, James (2002). "The Grand Tour and after (166)-1840)" in The Cambridge Companion to Travel Writing pp. 48-50.

12. Capelin, Belen S. (2008). Education Research Measurement and Evaluation Catsis, Petros et. Al. (2015) "What is Adaptability in Business". Operation for Increasing Adaptability of Employers and Employees to the Changes in Global Community. Küpe Sokak GOP Çankaya Ankara.

13. Chaney, E. (2000). The Evolution of the Grand Tour, revised ed. Routledge).

14. Coles, Tim, David Timothy Duval \& Gareth Shaw (2013). Student's Guide to Writing Dissertations and Theses in Tourism Studies and Related Disciplines.

15. Crawford, Sidnie Critto, A. (2000). Consistency: Being Coherent,. University Press of America 470 Boston Way Lanham, Maryland 20706 Publishing Company.

16. Drucker, Peter F. (2006). The Effective Executive: The Definitive Guide to Getting the Righ Things Done. New York: Collins.

17. El Daly, Okasha (2004). Egyptology: The Missing Millennium: Ancient Egypt in Medieval Arabic Writings. Routledge. p. 36. ISBN 1-84472-063-2.

18. Federici, S., Borsci S. (2010). Usability evaluation: models, methods, and applications. In: JH Stone, $M$ Blouin, editors. International Encyclopedia of Rehabilitation.

19. Fenner, D. W. E. (2008). Understanding Aestheti Value.,. Art in Context, Swallow Press, Ohio University Press Publishing Inc.

20. Fourie, P. J. (2006). Media Studies: Content, Audience \& Production, Credo Communication Inc. South Africa.

21. Fraser, M. (2004). Quality in higher education: an international perspective' in Green, D. (Ed.), What is Quality in Higher Education? Buckingham, Open University press and Society for Research into Higher Education. pp. 101-111.

22. Fretzer, A. (2007). Context and Appropriatenes, John Benjamins Publishing Company North Philedelphia PA USA. 
EPRA International Journal of Multidisciplinary Research (IJMR) - Peer Reviewed Journal Volume: 7 | Issue: 4 | April 2021|| Journal DOI: 10.36713/epra2013 || SJIF Impact Factor 2021: 8.047 || ISI Value: 1.188

23. Gassan, Richard (2005)." The First American Tourist Guidebooks: Authorship and Print culture of the 1820s. "Book History 8, pp. 51-74.

24. Gronau, A. K. N. (2005). An Approach to Increase Adaptability in ERP Systems. In: Managing Modern Organization with Information Management Association International Conference.

25. Holzinger, A. (2007). HCI and Usability for Education and Wor, Springs Science \& Business Media.

26. Ivey, G. (2010). Text That Matters, Reading to Learn, 67, 18-23.

27. Lehrer, Ehud and Dov Samet (2013). "Belief Consistency and Trade consistency". Games and Economic Behavior. The School of Mathematical Sciences, Tel Aviv University. Fontainebleau, France Elsevier Inc.

28. Nielsen, J. (2000). Coordinating User Interfaces for Consistency, Morgan. Kaufmann. Publisher. San Francisco, $\mathrm{Ca}$.

29. Nielsen, J. (2004). Usability Engineering. Morgan Kauffman Pub.

30. Pulakos, Elaine D. et al. (2000). Adaptability in the Workplace: Development of a Taxonomy of Adaptive Performance.

31. Rach, M. Halvorson, K, (2012). Content Strategy for the Web, Pearson Education Inc.

32. Richardson, J. Morgan, $R$ \& Fleener C. (2009). Reading to Learning in the Content Areas, Wadsworth, Cengage Learning Publishing.

33. Van der Geest, T. and Loorback, N. (2005). Testing the Visual Consistency of Websites. Technical Communication.

34. Whitla, William (2009). The English Handbook: A Guide to Literary Studies. Wiley-Blackwelin John Wiley \& Sons, Inc.

35. Woodhouse, Maria et. al. (2014). Referencing guide. (19th Rev. ed.). Joondalup, AustraliaL Edith Cowan University.

36. Garantuza, Eryl A. (2015). "Development and Validation of Module in Teaching Listening: Unpublished Master's thesis, Laguna State Polytechnic University, Main Campus, Sta. Cruz, Laguna.

37. Green, Jogn S. and Jovacic, Zilateo, J. (2012). "Automated Grading Spreadsheet and Database Skills". Open Polytechnic, Wellington, New Zealand, p. 68.

38. Alafaireet, Patricia et. al. (2009). Defining and Testing EMR Usability: Principle and Proposed Methods of EMR Usability Evaluation and Rating. Healthcare Information and Management Systems Society (HIMSS) HER Usability Task Force.

39. Arganoña, Antonio (2008). Consistency in Decision Making in Companies. "Humanizing the Firm and the Management Profession" Corporate Social Responsibility and Corporate Governance IESE Business School, University of Navarra for the Seminar IESE Business School.
40. Schillinger, D. (2010). An Introduction to Effectiveness, Dissemination and Implementation Research. P. Fleisher and E. Goldstein, eds. From the Series: UCSF Clinical and Translational Science Institute (CTSI) Resource Manuals and Guides CommunityEngaged Research, P. Fleisher, ed. Published by Clinical Translation Science Institute Community Engagement Program, University of California San Francisco.

41. Teal, C. R. and Street, R. L. (2009), Critical Elements of Culturally Competent Communication in the Medical Encounter: A Review and Model. Social Science and Medicine.

42. Fergusson, Daniella et. al (2012) Digital Sustainability Convesations. How Local Governments can Engage Resident Online. March 2012. 